\title{
Daniel's Cleopatra and Lady Anne Clifford: From a Jacobean Portrait to Modern Performance
}

Yasmin Arshad,

Early Theatre 17.2 (2014), 167-186

Helen Hackett,

DOI: http://dx.doi.org/10.12745/et.18.2.2548

and EMMA WHIPDAY

Recent interest in staging so-called 'closet dramas' by early modern women has bypassed Samuel Daniel's Cleopatra, because of the author's sex. Yet this play has strong female associations: it was commissioned by Mary Sidney Herbert, and is quoted in a Jacobean portrait of a woman (plausibly Lady Anne Clifford) in role as Cleopatra. We staged a Jacobean-style production of Cleopatra at Goodenough College, London, then a performance of selected scenes at Knole, Clifford's home in Kent. This article presents the many insights gained about the dramatic power of the play and its significance in giving voices to women.

Early in the early seventeenth century a young woman, costumed as Cleopatra, posed for a portrait, holding aloft the fatal asps (figure 1). She is not Shakespeare's Egyptian queen: an inscription on the portrait comes from the 1607 version of Samuel Daniel's Cleopatra. The sitter may have 'performed' the role of Cleopatra only for the portrait, or the portrait may record a fully staged performance of the play; either way, this Jacobean woman identified with Cleopatra and wanted to speak through Daniel's lines. We have reasons to identify the woman as Lady Anne Clifford, countess of Dorset (1590-1676), ${ }^{1}$ and the portrait may relate to her lengthy inheritance dispute, during which she defied her uncle, her husband, and even King James, just as Cleopatra defies Caesar in the play. Inspired by this possibility, we staged a performance of Daniel's Cleopatra in March 2013 at Goodenough College, London, and in June 2014 performed selected scenes at Knole House, Kent, Clifford's home. ${ }^{2}$ The processes of rehearsal and performance produced many insights into the dramatic qualities of Daniel's text and the opportunities it offers for voicing and performing female heroism.

Yasmin Arshad (y.arshad@ucl.ac.uk) is a doctoral student in English at University College London. Helen Hackett (h.hackett@ucl.ac.uk) is professor of English at University College London. Emma Whipday (emma.whipday@kcl.ac.uk) is a teaching fellow at King's College London and a Globe Education lecturer at Shakespeare's Globe. 


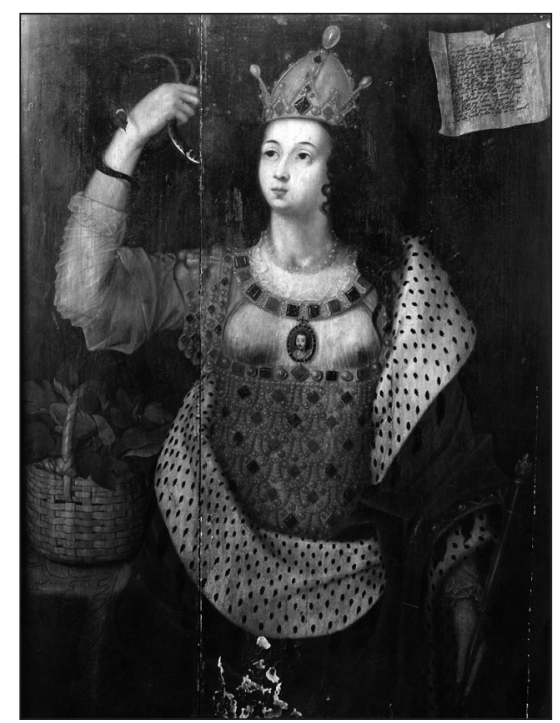

Fig. 1: 'Lady Ralegh as Cleopatra', by an unknown artist. Oil on panel, 109.2. x $82.5 \mathrm{~cm}$. Christie's 23 July 1948 (77). Photograph: National Portrait Gallery, London. Present whereabouts unknown.

\section{Female Devisership: Play and Portrait}

The connections of Daniel's Cleopatra with female authorship, patronage, and performance are strong. Mary Sidney Herbert, countess of Pembroke, ${ }^{3}$ commissioned the play as a sequel to Antonius (1592), her translation of Robert Garnier's French Senecan tragedy Marc Antoine. This translation was the first Cleopatra play in English, Daniel's the first original English play on this subject. As he explained in prefatory verses to the 1594 first edition of Cleopatra, it was 'the worke the which she [Mary Sidney] did impose', and he would not have written it,

Madam, had not thy well grac'd Anthony

(Who all alone having remained long,)

Requir'd his Cleopatras company. ${ }^{4}$

Margaret P. Hannay has emphasized the shared topical project of Mary Sidney's Antonius and Daniel's Cleopatra in the turbulent 1590s, when criticism of Elizabeth I's dilatory foreign policy and neglect of the succession grew among the 'forward' Protestant party: 'Insofar as Mary Sidney did sponsor drama, it was a drama that focused on political themes, 
particularly on the duties of the monarch. Both her translation of Marc Antoine and Daniel's sequel in Cleopatra focus on the conflict between private and public issues.'.

The plays were companion pieces, with Sidney's relation to Daniel's Cleopatra exemplifying female 'devisership', a term proposed by Peter Davidson and Jane Stevenson for the extensive cultural activities of early modern elite women which are not adequately described by the terms 'authorship' or 'patronage'. Davidson and Stevenson cite creative acts by Elizabeth, Lady Russell such as commissioning and designing elaborate tombs, and overseeing the entertainment offered when Elizabeth I visited her home at Bisham, in which Lady Russell's daughters performed speaking roles. They argue the 'case for expanding our ideas of what constitutes a cultural intervention to consider works that communicate a woman's intentions without necessarily being created by her own hand'. ${ }^{6}$ Mary Sidney's commissioning of Daniel's Cleopatra was just such an act of devisership, exercising artistic agency and conveying a message via a work executed by another.

Both Antonius and Cleopatra belong to the genre designated by modern critics (sometimes dismissively) as 'closet drama': plays, often neoclassical and elevated in tone, designed for reading aloud or private performance or something in-between among a privileged circle of family and friends in a domestic setting. Until recently so-called 'closet plays' - hereafter referred to in the present article as 'elite domestic plays' - were largely ignored by scholars of early modern drama. ${ }^{7}$ Recent attention, however, has substantially revalued the genre, revealing its potential for literary innovation, dramatic experiment, and political comment; the opportunities for literary and dramatic participation that it offered to women; and its performable qualities. Because access was restricted to a known social circle, the private house paradoxically opened up possibilities for female participation in drama. Sasha Roberts, discussing early female readers of Shakespeare's erotic narrative poem Venus and Adonis, has shown how the home and the closet, which look like forms of enclosure, in fact offered women spaces for intellectual independence. She observes that 'Feminist criticism has often associated women's privacy with their subordination - women's exclusion from the "public sphere"; the patriarchal "domestic enclosure" of women', but finds that 'We do not always need to write early modern women out of their homes in order to discover their opportunities for self-expression and empowerment. ${ }^{8}$ Roberts points to scenes in the Urania of Lady Mary Wroth (Mary Sidney's niece) where women withdraw into their private chambers to read, write, and explore their 
emotions without inhibition: Bellamira, for instance, describes 'being come to my chamber, and having liberty by privatenesse to exercise my sorrow'? Female participants in elite domestic drama could enjoy an analogous 'liberty by privatenesse', whether as translators (Lady Jane Lumley, Mary Sidney); authors of original drama (Elizabeth Cary, Mary Wroth); or devisers (Elizabeth Russell, Mary Sidney). Scholars have also increasingly come to believe that elite domestic drama offered women opportunities as performers. Even a static group reading would have constituted a form of performance, but recent experiments in staging Lumley's Iphigenia, Cary's Mariam, and Wroth's Love's Victory have demonstrated these plays' suitability for full staging.

Marta Straznicky points out that elite domestic plays were analogous to academic drama, which took place in a more private and privileged milieu than commercial playhouse drama, but nevertheless was 'not only read but performed at universities. ${ }^{10}$ Schools, universities, and the Inns of Court offered performance spaces for educated young men; similarly, the even more enclosed and regulated space of the country house made possible performance by women. Writing about Mary Sidney's Antonius, Alison Findlay acknowledges that 'how the play was realized in a private or communal reading or in a household performance is unknown'. She points, however, to 'the Sidney and Pembroke families' long-standing patronage of stageable drama' and to 'evidence of a tradition of reading and performance in the Pembroke household'. ${ }^{11}$ Mary Sidney's brother Sir Philip participated in domestic theatrical activities, confirmed by Edmund Spenser's elegy for him, 'Astrophel', which recalls that 'he himselfe seemd made for meriment, / Merily masking both in bowre and hall'. ${ }^{12}$ Findlay proposes that a staging of Antonius at Wilton, Penshurst, or Ramsbury (a smaller manor house from where Mary Sidney dated her translation manuscript) is plausible if we imagine a small coterie production drawing on clothes and objects from the household itself'. ${ }^{13}$ Hannay, having previously averred that 'a stageable Antonius would have taxed the resources of the Wilton household', now feels in the light of recent research that both Antonius and Daniel's Cleopatra could have been staged in private settings. ${ }^{14}$ Findlay asserts that 'we have ... reached a new critical frontier' where we can conceive of early modern elite domesitc plays as intended for performance, and can develop fresh analyses from this shift of view. ${ }^{15}$

Exciting evidence for a possible full staging of Daniel's Cleopatra emerges in the Jacobean portrait discovered by Yasmin Arshad in the archives of the 
National Portrait Gallery (NPG), London (figure 1). ${ }^{16}$ The inscription at top right, from Cleopatra's dying speech in Daniel's play, appears as a torn and unfolded manuscript, perhaps part of a player's script, implying that the sitter is speaking the lines. ${ }^{17}$ The present whereabouts of this portrait are unknown, and the NPG archives record it only as a monochrome photograph. Christie's have catalogued it twice, in 1931 and 1948, and on both occasions identify the sitter as Lady Raleigh (formerly Elizabeth Throckmorton), an identification repeated in the NPG record and in discussions of the painting by Kim F. Hall, Pamela Allen Brown, and Anna Beer. ${ }^{18}$ Only Beer identifies the inscription on the painting as from Daniel's Cleopatra, and she does not investigate the edition used, which is crucial to dating the portrait and identifying its sitter. Daniel was a habitual reviser and there were nine editions of Cleopatra, existing in five states. The portrait uses lines from either his much-revised 1607 edition or the 1611 reprint based on it. Excerpted from Cleopatra's final speech, ending with 'And now prowd tyrant Caesar doe thy worst', the lines purposefully accentuate Caesar's tyranny and Cleopatra's heroic defiance. Only one line of the inscription, the fourth from the end, differs from the 1607 print edition of Cleopatra. The print edition has: 'And Egypt now the Theater where I / Have acted this' (K7r), foregrounding theatricality and perhaps indicating staged performance of the play wherein this line would have formed a powerfully self-conscious moment. ${ }^{19}$ The portrait lines read 'And Egipt now where Cleopatra I / Have acted this', maintaining the idea of performance but placing more emphasis on the heroine's proud autonomy. ${ }^{20}$

In 1607 Lady Raleigh was forty-two years old, significantly older than the portrait sitter appears to be, and no known portraits of her resemble this Cleopatra. A clue to a more likely identification of the Cleopatra sitter appears in the 1607 edition of Daniel's Certaine Small Workes, the volume containing the version of Cleopatra quoted in the portrait. A sonnet to Anne Clifford implies that Daniel would like to dedicate everything in the volume to her, but cannot do so because some works have already been dedicated to others (Cleopatra, for example, commissioned by and dedicated to Mary Sidney): ${ }^{21}$

I Cannot give unto your worthines

Faire hopefull Lady these my legacies

Bequeath'd to others, who must needs possesse

The part belonging to their dignities. 
The word 'hopefull', implying promise, alludes to Clifford's youthfulness; she was seventeen in 1607. Daniel then nominates Clifford as guardian of his works and his literary executor:

\section{I here desire}

To make you supravisor of my will

And do intreat your goodnesse to fulfil

My last desires left unto you in trust

I know you love the Muses, and you will

Be a most faithfull Guardian and a just.

And therefore I do so leave all to you

That they may both have theirs \& you your due.

$(\mathrm{A} 7 \mathrm{r})$

The theme of inheritance alludes to the notorious property dispute in which Clifford had become embroiled since her father's death in 1605, when, because of her sex, her family's vast northern estates had passed to her uncle. ${ }^{22}$ Daniel suggests that although the debate about rights to those estates may not be going her way, Clifford can at least consider herself the heir to his works. The sonnet may also function as a deft transfer of patronage, maintaining recognition of Mary Sidney's importance to Daniel while allowing a share in ownership of his works to Clifford, especially in terms of preserving and protecting them for the future. We may surmise that Clifford now regarded the text of Cleopatra as in some sense belonging to her. ${ }^{23}$

Daniel had long-standing personal, literary, and dramatic associations with Clifford. In 1592 he had published a highly successful poem related to her family history and celebrating tragic femininity, The Complaint of Rosamond (a female complaint in the voice of the ghost of Rosamond Clifford). Daniel then became Clifford's tutor from around 1599, when she was aged nine, to 1602 , and was a strong influence in these formative years. ${ }^{24}$ Their mutual esteem and affection endured and developed. In 1610, a year after Clifford's marriage to Richard Sackville, third earl of Dorset, Daniel cast her as the nymph of Aire, the river that ran past her birthplace, Skipton Castle, in his court masque Tethys' Festival. ${ }^{25}$ Clifford and Daniel were frequently together in the entourage of Queen Anne of Denmark, and Daniel supported Clifford in her inheritance dispute against her husband and King James. ${ }^{26}$ Clifford's biographer Richard T. Spence observes that 'there was hardly a hiatus in Anne's links with Daniel up to his death in 1619 '; 27 indeed many years later Clifford commemorated Daniel's importance to her by including him in her Great Picture (1646), a triptych portrait of her family and herself 
in youth and age. The left-hand panel depicts Clifford aged fifteen, with an inset portrait of Daniel behind her, inscribed 'Samuel Daniel Tutour to this Young Lady a man of an Upright and excellent Spirit'. ${ }^{28}$ The extensive use of inscriptions in the Great Picture, presented as if on slips of paper, strongly resembles the inscription in the Cleopatra portrait. Also in the lefthand panel is a shelf of the books that were important to Clifford in her youth, including Daniel's Chronicles of England and All the Works in Verse. ${ }^{29}$ In 1654, Clifford commemorated Daniel again by erecting a monument to him at Beckington Church in Somerset. ${ }^{30}$

Resemblances between the Cleopatra painting and portraits of Clifford as a young woman all show a round face with rather full cheeks, dark eyes and thick dark hair, a small mouth with a full lower lip, and a dimpled chin. ${ }^{31}$ Clifford's parents were patrons of music and drama and her education and early adulthood embraced various kinds of performance, including dancing, playing music, and participating in masques. ${ }^{32}$ As well as Daniel's Tethys' Festival (1610), she also performed at court in Ben Jonson's Masque of Beauty (1608) and Masque of Queens (1609), and regularly attended court masques after her marriage. ${ }^{33}$ The masque roles played by aristocratic women were silent, whereas Daniel's Cleopatra has many lines to speak. In the 1592 Bisham entertainment, however, the daughters of the Russell family played scripted roles, demonstrating that elite women did play speaking parts in country house performances. ${ }^{34}$

Intriguingly, Clifford's role in The Masque of Queens was Berenice - like Cleopatra, a queen of Egypt. Berenice was famed for her hair (which she sacrificed as a votive offering), which perhaps explains the casting of Clifford in this role: she later recalled that in her youth her hair 'was Browne and verie thick and so long that it reached the Calfe of my Legges when I stood upright'. ${ }^{35}$ Thick, dark, flowing hair is a striking feature of an Isaac Oliver miniature of ca 1608/9 of Clifford in a masque costume, ${ }^{36}$ as also of the lady in the Cleopatra portrait. In The Masque of Queens, Inigo Jones designed a headdress for Clifford as Berenice (to conceal her 'severed' hair) which resembles the headdress in the Cleopatra portrait. Other similarities between the two costumes include the drapery of the robes, the necklaces, and the diaphanous covering of the breasts. Clifford could have adapted the costume of one Egyptian queen to play another, either in a staged performance recorded by the Cleopatra portrait, or in posing for the portrait itself. ${ }^{37}$ Some evidence suggests court masquers paid for their own expensive costumes and 
retained them afterwards: Clifford's husband the earl of Dorset, for instance, had yellow masquing stockings in his possession in 1619.38

Expounding their concept of female devisership, Davidson and Stevenson observe that: 'the person above all whose life and work becomes more comprehensible if she is identified as a deviser is Lady Anne Clifford ... Her personal agenda is eloquently declared by a whole set of artefacts, none of which is from her own hand: the "Great Picture" that she commissioned; the buildings she created or repaired; and, not least, the highly elaborate tombs of herself and her mother. ${ }^{39}$ All the artefacts they mention were devised later in her life, but they accord with a hypothesis that Clifford 'devised' and sat for the Cleopatra portrait, in some sense appropriating Daniel's play as her own, and perhaps performed in it.

Daniel's Cleopatra would have had strong personal relevance for Clifford at various points in her early life. When Daniel was her tutor, between her ages of nine and twelve, they may have read his play together, and he could have encouraged her to perform lines from it: just as boys at school and university performed drama to prepare them for public life, inhabiting the role of Cleopatra would have educated Clifford in public speech and the authoritative bearing of a queen. This training would befit a girl destined by birth to be a leading aristocrat in her society, and, if she inherited her father's lands and titles as her mother wished, to fulfil important public roles at court and in the local administration of the Clifford estates. ${ }^{40}$

If we accept that the woman in the Cleopatra portrait is Clifford, and that she recycled her Berenice masquing robes to sit for the portrait, then its earliest possible date is 1609 , when Clifford was nineteen and her inheritance dispute had been running for around three years. If she played Cleopatra in a staged performance around this time it may have reminded her of happier times with Daniel, but it could also have enhanced her confidence in fighting her cause. Alternatively if she played the role a few years later, around 1615-17, when she was a wife in her mid-twenties, it would have reverberated profoundly with the acrimonious state of her inheritance dispute at that time. Her husband sometimes took her part and sometimes opposed her, according to where he saw the greatest potential financial or political advantage. At this period he was against her, placing her in conflict with all the principal male authorities in her life: uncle, husband, and king. In 1615 she wrote to her mother that 'by the power of God I will continue resolute and constant', and 'I will stand as constantly to my birthright as is possible for me. ${ }^{41}$ Nevertheless she was torn between allegiance to her beloved mother 
and to a husband for whom, in spite of everything, she consistently professed her love. ${ }^{42}$ She perhaps identified with Cleopatra when she asks, 'O my divided soule what shall I doe? / Whereon shall now my resolution rest?' (G6v). In May 1616, in one of his harshest actions towards her, Sackville took away their daughter Margaret, and Clifford recorded that 'this was a very grievous and sorrowful day to me.' 43 Again she may have found a resonance with Cleopatra's lines on parting from her son Caesario: 'That blood within thy vaines came out of mine / Parting from thee, I part from part of me'. ${ }^{44}$ In her diary for 1617 Clifford relates how King James sometimes 'used fair means $\&$ persuasions, \& sometimes foul means' to urge her to accept a settlement 'but I was resolved before so as nothing would move me'. She told the king 'I would never part with Westmoreland while I lived upon any Condition whatsoever'. 45 Similar defiance and identification with her land ring through Cleopatra's dying words, the lines inscribed (in slightly modified form) on the portrait:

\section{And Egypt now the Theater where I \\ Have acted this, witnes I die unforc'd, \\ Witnes my soule parts free to Antony, \\ And now prowd tyrant Cesar doe thy worst.}

As a woman assertive enough to play Cleopatra, Clifford may have gained even greater public confidence by actually playing the role. Spence notes that after summer 1617 she became more socially engaged and self-sufficient, spending more on clothes, gifts, and monuments to her mother and others. ${ }^{46}$ William Larkin painted her portrait in 1618, and Paul van Somer painted her in 1619, with two further portraits of 1619-20 deriving from the van Somer image. ${ }^{47}$ If the Cleopatra portrait belongs to this period it would accord with Clifford's increasing independence from her husband and development of her own cultural interests, including fashioning her own image. She turned thirty in 1620, still a plausible age for the portrait's sitter. The painting could even date from the early years of Clifford's widowhood following Sackville's death in 1624, when she was entirely autonomous and financially comfortable.

\section{Staging Cleopatra I: Goodenough College, 3 March $2013^{48}$}

We were eager to explore how the 'embodiment' of Cleopatra in rehearsal and performance might illuminate the play. ${ }^{49}$ How stageable is the play, and 
what might performing Daniel's Cleopatra have meant to a young woman like Clifford?

Student auditions gathered a predominantly female cast of mixed ethnicities and ages. We cast two young professional actors in the leading roles: ${ }^{50}$ Charlotte Gallagher as Cleopatra (figure 2), and Beth Eyre as Octavius Caesar. At first we aspired to a form of 'original practices' production, while acknowledging the contested definitions and diverse approaches generated by this term. ${ }^{51}$ We provided cast workshops on moving in Jacobean costume (run by Eve Goodman, an expert in historical costume), and on Jacobean acting (run by Philip Bird, an actor at Shakespeare's Globe and director of plays for their Read Not Dead programme). Music was selected by Simon Smith (who has researched music for productions and staged readings at the Globe), and lutenist Sam Brown (from the Royal College of Music), including compositions by John Danyel, Samuel Daniel's brother. ${ }^{52}$ Costuming was guided by Henry Peacham's often reproduced 1590s sketch of Titus Andronicus and by Philip Henslowe's inventories, ${ }^{53}$ both of which indicate that early modern theatrical costumes were basically Elizabethan or Jacobean with small details, such as armour, cloaks, and jewellery, suggesting specific dramatic period and location. We had several long-haired young women playing male roles, including Caesar, and dealt with this by sweeping their hair over one shoulder, as in somewhat androgynous portraits of Henry Wriothesley, earl of Southampton. ${ }^{54}$

Other factors meant, however, that the production was inevitably hybrid or 'Jacobean-style'-what Rob Conkie calls 'originalish practices'. ${ }^{55}$ Reproducing the costume in the Cleopatra portrait was prohibitively expensive, while our venue was the 1930s-built Great Hall of Goodenough College, an academic community of several hundred postgraduate students. Even so, this space offered its own opportunities for translation of the practices of Jacobean elite domestic drama into modern forms. Alison Findlay and Stephanie Hodgson-Wright observe that 'Domestic performances ... relied on the resources already available in the household'; 56 accordingly we sourced props and accessories from the homes of our cast and crew. We rented costumes, including a gown for Cleopatra worn by Helen Mirren playing Elizabeth I for television in 2005. ${ }^{57}$ This re-use paralleled Clifford's recycling her Berenice costume from a glamorous court performance to play Cleopatra in a more intimate domestic setting, and added irony to the implied criticism of Elizabeth in Daniel's play. 


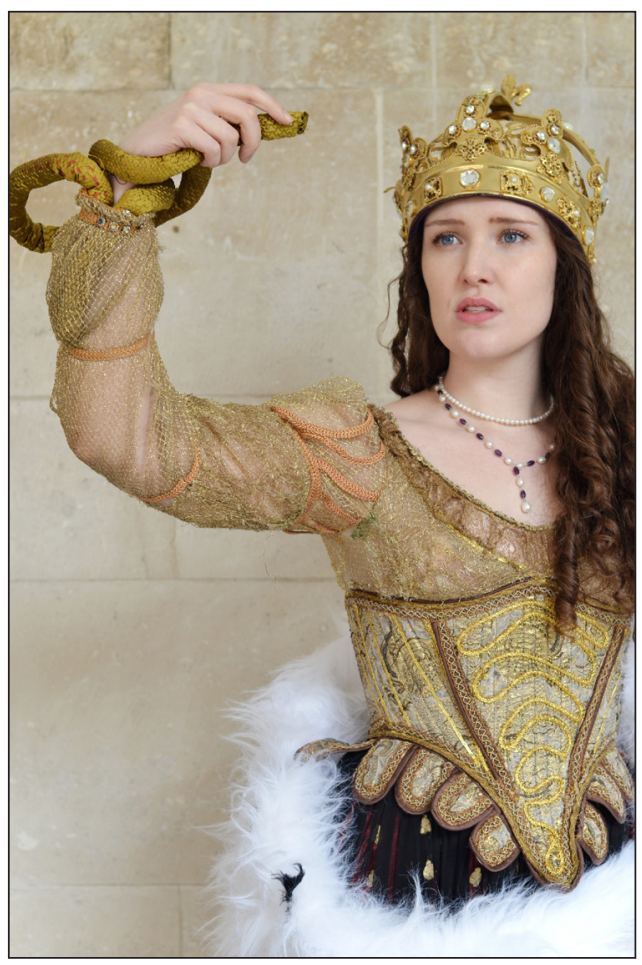

Fig. 2: Charlotte Gallagher as Daniel's Cleopatra, recreating the pose in the Cleopatra portrait, CYi Ling Huang, 2013.

Findlay has observed that 'In private theatricals, the house becomes a stage on which actors perform in a fictional setting, but the venue is simultaneously a social space in which authors and actors live'.58 Goodenough College is in effect a large household, where the Great Hall is used for daily meals, formal dinners, and communal celebrations and entertainments, not unlike a Jacobean Great Hall. Although built in the 1930s, it is in 'Jacobethan' style, with high vaulted ceilings and oak panelled walls. ${ }^{59}$ This imitation of the early modern is disrupted by present-day features such as electric chandeliers and modern portraits, but even these created dialogues with our performance: some spectators commented on the fact that our Cleopatra embodied queenship in front of a striking modern portrait of Queen Elizabeth II. ${ }^{60}$

Our performance used the 1607 edition of Cleopatra, as in the portrait inscription. This edition is Daniel's last major reworking of the play, moreover, and his revisions suggest traces of performance experience. ${ }^{61}$ He uses 
fewer soliloquies than in earlier versions, less narration, more references to props, and slightly fuller references to movement, such as 'Goe', 'Stay', and 'Rise, madame, rise'(G6v, I2v). Early read-throughs highlighted the theatricality of the text and implicit performance cues indicated gesture and movement, as in the very opening line: 'Come Rodon, here' (G5r).

We made some minor textual alterations to improve accessibility and to meet practical constraints. We cut some incidental lines from long speeches to reduce the overall running time from nearly two-and-a-quarter hours to under two hours. As Lukas Erne points out, early modern audiences accustomed to hearing long and complex sermons were probably more attentive and patient than audiences today. ${ }^{62}$ Erne also shows that printed versions of playhouse plays were often longer - more literary, more suitable for reading - than the script as performed, and this speculation might apply to elite domestic plays too. ${ }^{63}$ To accommodate the nineteen characters indicated in the text to our company of fifteen we also cut or amalgamated some characters and doubled some roles, as was standard practice for playhouse and touring plays. ${ }^{64}$

Our practical adjustments are simply dramaturgy, responding to the particular conditions of the performance. Following neoclassical conventions, for example, characters frequently narrate the off-stage actions of others, a device unfamiliar to most modern audiences. For two particularly challenging passages, where Roman officers report long speeches by Cleopatra, we gave the lines to Cleopatra herself, treating the scenes as flashbacks, with lute accompaniment indicating the co-existence of two temporal planes. Derek Dunne described this staging choice as 'one of the most inspired touches in the production', and noted that it 'allowed a far more expressionistic use of the stage space to emerge, as multiple geographical and temporal zones seemed to overlap'. ${ }^{65}$

These scenes emphasize that Cleopatra is an actor, constantly playing to an audience: 'the fortune-following traines' (H3r) who once surrounded her; the 'prease' (press) (G8v) of onlookers who watched her raise the dead Antony; the court who modelled their manners on hers, to their own downfall (K3v). She also performs for specific individuals. In 3.2 her climactic encounter with Caesar implies a stage direction in his line 'Rise madame, rise' (I2v). We experimented with different ways of playing this action and consistently found great dramatic intensity in the scene. Gallagher's Cleopatra prostrated herself before Caesar, a gesture both flirtatious and sardonic that deepened his frustration and impotence. She aimed her performance 
entirely at Caesar, ignoring both her own servant, Seleucus, who is about to betray her, and the watching Dolabella, whose ensuing love for her will take her by surprise.

Embodiment accentuated the dynamics of the play: this confrontation between Cleopatra and Caesar was fraught with a tense combination of mutual fascination and disgust, and invoked the sexual politics of Cleopatra's previous relations with Rome. By contrast, the quiet attentions of her handmaids to Cleopatra's comfort and appearance had a domesticity and intimacy which sprang to life in performance. The choruses, another neoclassical dramatic convention unfamiliar to modern audiences, provided a rhythm to the action and powerful moments of meta-theatrical reflection; whilst Cleopatra's monologues beside Antony's corpse, somewhat repetitious on the page, became in performance an enthralling, if circuitous, journey through the various stages of grief. Gallagher found that having 'very long speeches with no-one interrupting you' was unproblematic because 'Daniel's thought progression helps you remember the lines'. ${ }^{66}$ Eyre (playing Caesar) was similarly 'surprised by how performable even these very long speeches are and how well they work as a method of storytelling'. She was struck by 'how dynamic the scenes between Caesar and Cleopatra are and how clear and natural the dialogue felt'. She also enjoyed 'how Daniel's play provides many of the characters with moments where they take the spotlight and come into their own'67 — perhaps an effect of writing for a household performance which gives a turn to each member of the family or party.

\section{Staging Cleopatra II: Knole House, 23 June 2014}

The National Trust invited us to give a presentation at Knole House, Kent, including performance of selected scenes from Cleopatra. Knole was Clifford's home from 1609 to 1624, so if she played Daniel's Cleopatra it is the likeliest venue. Our event was in the Great Hall, a large, imposing chamber with a tessellated floor and walls partly wood-panelled with portraits hanging above. ${ }^{68}$ The sense of place and direct historical connection with Clifford gave exciting resonance to our performance, but even at Knole compromises were necessary in staging a modern event. The scenes took place on the raised dais at the far end of the Hall: partly because to the modern eye this is the most obviously stage-like space in the room, with its slight elevation improving visibility; but also for practical reasons including access to electrical sockets and leaving the audience's entrance route clear. A Jacobean 
performance, however, was more likely at the opposite end of the Hall, where a magnificent carved wooden screen has two doors for cast entrances and exits. ${ }^{69}$ In rehearsal the acoustics of the Hall were wonderful for our lute accompanist, but problematic for actors' voices, which reverberated or failed to reach parts of the room. Once our audience of around 100 was in place the acoustics considerably improved, and they may have been even better in the seventeenth century with rushes on the floor and tapestries on the walls.

The Knole performance took place as the golden glow of a midsummer's evening slanted through the high windows of the ancient hall and embraced performers and audience alike. For reasons of expense and practicality, instead of the elaborate Jacobean-style costumes used at Goodenough, we used understated modern clothing, but found that scenes worked equally well without the visual allure of period dress. We had some cast changes, with actors who had taken supporting roles at Goodenough stepping up to play Cleopatra (Elspeth North) and Caesar (James Phillips), with great success. While they brought their own personal qualities to the characters, they achieved just as much political and sexual tension as at Goodenough. Again the actors found Daniel's long speeches surprisingly unproblematic. North considered them 'easier to learn than Shakespeare' because of rhyme ( $a b a b)$ and regular verse lines: 'you can hear when you're missing a beat or saying the wrong word at the end of the line'. Like Gallagher, she found that 'Daniel creates thought sequences that allowed me to think my way logically through the speeches. ${ }^{70}$

\section{Playing Cleopatra: Then and Now}

The embodiment of Cleopatra by actors highlighted Daniel's distinctive view of female heroism. Outside drama he explored tragic femininity in the fashionable genre of female complaint, in his Complaint of Rosamond (1592) and Letter from Octavia (1599). Influenced by Ovid's Heroides, this genre enables the extensive exploration of female subjectivity and the female voice, and Cleopatra is arguably a female complaint in dramatic form. ${ }^{71}$ Staging the play foregrounded the term 'confusion', which with its cognates occurs eleven times in the text: Cleopatra is 'Twixt majestie confus'd, and miserie' (H6r), caught in conflict between her public duty as queen and her private passions as lover and mother. ${ }^{72}$ The play criticizes the political confusion that her private confusion brings to Egypt, and in the 1594 version would have implied critique of Elizabeth I's vacillations and failure to secure the succession. ${ }^{73}$ Yet 
Daniel somewhat exonerates his Cleopatra with her self-blame for Egypt's downfall, and also gains depth and pathos from her self-division. In scenes like the one where she receives a love-letter from the Roman Dolabella, and 'mus'd a while, standing confusedly' (K4r), Daniel finds psychological and emotional complexity and makes a virtue of Cleopatra's confusion. ${ }^{74}$

For Gallagher, the first of our present-day Cleopatras, these divided states were the key to the character: 'I really loved her vulnerability and not knowing what to do'. At the same time she found many aspects of the role 'empowering', especially the death scene: 'everything is within her in that moment. ${ }^{75}$ Emma Whipday as director observed that Gallagher found her way into the role through emotional volatility and intensity. She vacillated between conflicting roles - proud queen, desperate mother, and grieving lover - while still creating a sense of a continuous character. By finding a series of distinct emotional moments in Daniel's lines Gallagher was almost able to 'stack' or overlay these emotions, so that the audience was still aware of the private, grieving woman while watching Cleopatra's power-play with Caesar as a deposed queen. Reviewers greatly admired this approach, especially Mary Ellen Lamb, who noted how Gallagher 'breaks up long speeches into a series of distinct emotions to create a drama of a character's interior states', presenting 'a nuanced state of several emotional levels'. Consequently Lamb found herself reminded of Hamlet more than Shakespeare's Cleopatra. $^{76}$

North, an untrained and younger actor, approached the role differently, but with equal success. She worked with Whipday on portraying power by 'owning' the stage and using other characters' reactions to her presence and movements to reinforce her sense of herself as queen. Both actors found it helpful to imagine how Clifford might have felt if she played the role. North, playing Cleopatra at Knole, felt 'very aware' of Clifford and her personal circumstances: 'I felt like I was playing Anne Clifford playing Cleopatra at times'. ${ }^{77}$ Gallagher noted the 'heady freedom', 'transgressive pleasure', and 'exhilaration' that Clifford could have experienced from 'playing by different rules' for a few hours: 'it must have made the return to her everyday self very difficult indeed'. She picked out a couplet spoken by a penitent Cleopatra as she recalls her life before Antony: 'My vagabound desires no limits found, I For lust is endlesse, pleasure hath no bound' (H5r). Gallagher observed: 'The imagination is unfastened and uncensored in the space of that rhyme. Where does your mind go? What are your vagabond desires? No one knows what 
visions the player sees saying those lines, but the audience enjoys seeing the result of their thoughts show in their face, voice, and body. ${ }^{78}$

Reviewing our production Marion Wynne-Davies noted that 'early modern plays often appear to be unperformable because - with the telling exception of some of Shakespeare's canon - we don't often see them performed. Reviving plays written by dramatists of the sixteenth and seventeenth centuries is, therefore, more than a scholarly exercise; rather, it demonstrates the imaginative power of previously neglected works in a public arena'. ${ }^{79}$ We are satisfied that our project demonstrated the 'imaginative power' of Daniel's Cleopatra on stage, and thereby, combined with the evidence of the portrait, has added weight to the case that the play was staged in its own time, and offered opportunities for performance by women.

\section{Notes}

This essay is dedicated to the memory of Emily Stiff.

We would like to thank all the cast and crew of our production of Daniel's Cleopatra. The project was supported by the UCL Centre for Early Modern Exchanges and sponsored by the UCL Grand Challenge of Intercultural Interaction, The Malone Society, Oxford Journals: Music and Letters, UCL European Institute, UCL Faculty of Arts and Humanities, including FIGS (the Faculty Institute of Graduate Studies), UCL English department, and UCLU Drama Society. We are also grateful to the many colleagues, students, and friends who supported the project in various ways.

1 Hereafter referred to as Clifford.

2 Selected scenes were also performed at the UCL Arts Festival; and at the Shakespeare Institute, Stratford-upon-Avon, at a symposium ('Reanimating Playbooks', May 2013), and at a presentation funded by the Shakespeare Institute Players (November 2013).

3 Hereafter referred to as Mary Sidney.

4 Samuel Daniel, Delia and Rosamond Augmented. Cleopatra (London, 1594), H5r. In quotations from early modern texts $\mathrm{i} / \mathrm{j}$ and $\mathrm{u} / \mathrm{v}$ have been silently modernized. We quote lines elsewhere parenthetically from the 1607 Daniel edition, cited at 19n below.

5 Margaret P. Hannay, Philip’s Phoenix: Mary Sidney, Countess of Pembroke (Oxford, 1990), 125. 
6 Peter Davidson and Jane Stevenson, 'Elizabeth I's Reception at Bisham (1592): Elite Women as Writers and Devisers', Jayne Elisabeth Archer, Elizabeth Goldring, and Sarah Knight (eds), The Progresses, Pageants, and Entertainments of Queen Elizabeth I (Oxford, 2007), 223-4.

7 See for instance John D. Cox and David Scott Kastan (eds), A New History of Early English Drama (New York, 1996).

8 Sasha Roberts, 'Shakespeare "Creepes Into the Womens Closets About Bedtime": Women Reading in a Room of Their Own', Gordon McMullan (ed.), Renaissance Configurations: Voices/Bodies/Spaces, 1580-1690 (Basingstoke, 1998), 57-8.

9 Mary Wroth, The Countesse of Mountgomeries Urania (London, 1621), 332.

10 Marta Straznicky, Privacy, Playreading and Women's Closet Drama 1550-1700 (Cambridge, 2004), 17.

11 Alison Findlay, Playing Spaces in Early Women's Drama (Cambridge, 2006), 23.

12 Edmund Spenser, 'Astrophel', ed. Richard A. McCabe, The Shorter Poems (Harmondsworth, 1999), 374, lines 27-8.

13 Findlay, Playing Spaces, 29.

14 Hannay, Philip's Phoenix, 120; private correspondence, 13 November 2009.

15 Findlay, Playing Spaces, 9.

16 See Yasmin Arshad, 'The Enigma of a Portrait: Lady Anne Clifford and Daniel's Cleopatra', British Art Journal 11.3 (Spring 2011), 30-6; 'Imagining Cleopatra: Performing Race, Gender and Power in Early Modern England', PhD thesis (University College London, forthcoming 2016), ch. 4.

17 For a close-up image of the inscription, see Arshad, 'Enigma', 30.

18 Kim F. Hall, Things of Darkness: Economies of Race and Gender in Early Modern England (Ithaca NY, 1995), 183-7; Pamela Allen Brown, 'A New Fable of the Belly: Vulgar Curiosity and the Persian Lady's Loose Bodies', Dympna Callaghan (ed.), The Impact of Feminism in English Renaissance Studies (Basingstoke, 2007), 171-92; Anna Beer, My Just Desire: The Life of Bess Raleigh, Wife of Sir Walter (New York, 2003), 130.

19 Samuel Daniel, 'The Tragedie of Cleopatra', in Certaine Small Workes (London, 1607). All quotations are from this edition, and entered parenthetically in the body of the essay.

20 Arshad, 'Enigma', 32.

21 Daniel, Certaine Small Workes, as pointed out by John Pitcher in private conversation 20 November 2009.

22 See Ch. 3, 'The great inheritance dispute, 1606-17', in Richard T. Spence, Lady Anne Clifford: Countess of Pembroke, Dorset and Montgomery (1590-1676) (Stroud, 1997), 40-58. 
I84 Issues in Review

23 Arshad, 'Enigma', 34; 'Imagining Cleopatra', ch. 4.

24 Spence, Lady Anne Clifford, 12-17.

25 Ibid, 61.

26 Ibid, 62 and 65.

27 Ibid, 62.

28 Ibid, 187.

29 Ibid, 190.

30 Ibid, 151.

31 See William Larkin, Anne, Countess of Pembroke (Lady Anne Clifford), ca 1618, NPG 6976, http://www.npg.org.uk/collections/search/portrait/mw235435/Anne -Countess-of-Pembroke-Lady-Anne-Clifford. See also the portrait of Lady Anne Clifford at Skipton Castle: A Complete Medieval Fortress: History and People, http:// www.skiptoncastle.co.uk/hist.asp?page=3; and see Arshad, 'Enigma', 34.

32 Spence, Lady Anne Clifford, 15.

33 Ibid, 62, 66, and 76.

34 See Jean Wilson, Entertainments for Elizabeth I (Woodbridge, 1980), 43-7.

35 Spence, Lady Anne Clifford, 20.

36 Ibid, 22, figure 11.

37 Inigo Jones, design for Lady Anne Clifford's masque costume as 'Berenice Q of the Ægiptians' in The Masque of Queens, 1609, Chatsworth House, Derbyshire; see Arshad, 'Enigma', 34.

38 Martin Wiggins in association with Catherine Richardson, British Drama 15331642: A Catalogue, vol. 6 (Oxford, forthcoming).

39 Davidson and Stevenson, 'Elizabeth I's Reception', 224-5.

40 Spence, Lady Anne Clifford, 41 and 42.

41 Ibid, 53.

42 Ibid, 59-60.

43 Clifford, Diaries, May 1616, 32.

44 Ibid.

45 Lady Anne Clifford, Diaries (January 1617), ed. D. J. H. Clifford (Stroud, 1990), 45.

46 Spence, Lady Anne Clifford, 69-71.

47 Ibid, 73-7.

48 Produced by Yasmin Arshad, directed by Emma Whipday, with Helen Hackett as executive director. A DVD of the performance is available by emailingy.arshad@ucl. ac.uk or h.hackett@ucl.ac.uk, and a project blog is at https://thetragedieofcleopatra .wordpress.com/.

49 Rob Conkie, 'Rehearsal: The Pleasures of the Flesh', Shakespeare Bulletin 30.4 (Winter 2012): 413-14, 417, and 425. doi: http://dx.doi.org/10.1353/shb.2012.0077. 
50 Antony is dead before the action of the play begins, and appears only as a shrouded corpse.

51 See Alan C. Dessen, “'Original Practices” at the Globe: A Theatre Historian's View', Christie Carson and Farah Karim-Cooper (eds), Shakespeare's Globe: A Theatrical Experiment (Cambridge, 2008), 45; Farah Karim-Cooper, 'Props', Stuart HamptonReeves and Bridget Escolme (eds), Shakespeare and the Making of Theatre (London, 2012), 91.

52 Samuel signed his name 'Daniel' and John as 'Danyel'. These are the spelling conventions applied by modern scholars.

53 Henry Peacham, 'Enter Tamora pleadinge for her sonnes going to execution', Longleat House, Wiltshire, PO/Vol. 1: 1516-1612, item 54; Philip Henslowe, 'Diary and Account Book of Philip Henslowe, 1592-1609', Henslowe-Alleyn Digitisation Project MSS7, http://www.henslowe-alleyn.org.uk/catalogue/MSS-7.html.

54 See, for example, unknown artist, Henry Wriothesley, 3rd Earl of Southampton, ca 1600, NPG L114, London.

55 Conkie, 'Rehearsal', 427.

56 Alison Findlay and Stephanie Hodgson-Wright, 'Introduction', Alison Findlay and Stephanie Hodgson-Wright with Gweno Williams, Women and Dramatic Production 1550-1700 (Harlow, 2000), 2.

57 Elizabeth I (2005), written by Nigel Williams, directed by Tom Hooper, Channel 4.

58 Findlay, Playing Spaces, 18.

59 See 'The Great Hall', Goodenough College, London, http://events.goodenough. ac.uk/function-rooms/the-great-hall

60 For comment see Derek Dunne, 'Play review: The Tragedie of Cleopatra', Cahiers Élisabéthains 83 (Spring 2013), 44, doi: http://dx.doi.org/10.7227/ce.83.1.5; and Mary Ellen Lamb, Performance and DVD Reviews: 'The Tragedie of Cleopatra', Early Modern Women, An Interdisciplinary Journal 9.2 (Spring 2015), 148-52.

61 Arshad, 'Imagining Cleopatra', ch. 5.

62 Lukas Erne, Shakespeare as Literary Dramatist (Cambridge, 2003), 227.

63 Ibid, passim.

64 See Peter H. Greenfield, 'Touring', Cox and Kastan, New History, 254 and 264; W. R. Streitberger, 'Personnel and Professionalization', Cox and Kastan, New History, 340; Hugh Macrae Richmond, Shakespeare's Theatre: A Dictionary of his Stage Context (New York, 2002), 89 (entry on 'casting'), 151 (entry on 'doubling').

65 Dunne, 'Play review of Cleopatra', 43.

66 Charlotte Gallagher, interview with Arshad, 6 June 2013.

67 Beth Eyre, interview with Arshad, 22 May 2014.

68 John Henry Brady, The Visitor's Guide to Knole (1839), 102. 
I86 Issues in Review

69 Marion O’Connor, University of Kent, private communication.

70 Elspeth North, interview with Arshad, 8 July 2014.

71 John Kerrigan (ed.), Motives of Woe: Shakespeare and 'Female Complaint': A Critical Anthology (Oxford, 1991); Arshad, 'Imagining Cleopatra', chs 3 and 5.

72 Arshad, 'Imagining Cleopatra', chs 3 and 4.

73 See Hannay, Philip’s Phoenix, 38-42; Paulina Kewes, “'A Fit Memorial For The Times To Come...": Admonition and Topical Application in Mary Sidney's Antonius and Samuel Daniel's Cleopatra', Review of English Studies 63:259 (2012): 24364, doi: http://dx.doi.org/10.1093/res/hgr047.

74 Arshad, 'Imagining Cleopatra', ch. 3.

75 Gallagher, interview with Arshad, 6 June 2013.

76 Lamb, 'The Tragedie of Cleopatra', prepublication copy Lamb sent to Helen Hackett, unpaginated.

77 North, interview with Arshad, 8 July 2014.

78 Email from Charlotte Gallagher to Helen Hackett, 13 August 2014.

79 Marion Wynne-Davies, 'Review of Samuel Daniel's Tragedie of Cleopatra', Shakespeare (2013), 1. doi: 10.1080/17450918.2013.833982 